\title{
CHARACTER EVOLUTION OF THE BENTHIC THECATE DINOFLAGEL- LATE, GAMBIERDISCUS (DINOPHYCEAE), WITH AN INTRODUCTION OF THE INTERACTIVE KEY TO SPECIES
}

\section{Nurin Izzati Mustapa ${ }^{1}$, Sing Tung Teng ${ }^{2}$, Toh Hii Tan ${ }^{3}$, Hong Chang Lim ${ }^{1}$, Po Teen Lim $^{1}$ and Chui Pin Leaw ${ }^{1, *}$}

\author{
${ }^{1}$ Bachok Marine Research Station, Institute of Ocean and Earth Sciences, University of Malaya, 16310 \\ Bachok, Kelantan, Malaysia. \\ ${ }^{2}$ Faculty of Resource Science and Technology, Universiti Malaysia Sarawak, 94300 Kota Samarahan, \\ Sarawak, Malaysia. \\ ${ }^{3}$ Institute of Biodiversity and Environmental Conservation, Universiti Malaysia Sarawak, 94300 Kota Sama- \\ rahan, Sarawak, Malaysia. \\ *Corresponding author: cpleaw@um.edu.my
}

\begin{abstract}
The genus Gambierdiscus is one of the benthic marine dinoflagellates that are known to produce biotoxins, causing ciguatera food poisoning (CFP) in humans after consuming the contaminated marine fishes. These benthic marine dinoflagellates are commonly found in the warm tropical and subtropical waters. The phenomena associated with high cell abundance or "blooms" is referred to Benthic Harmful Algal Blooms (BHABs). Precise species identification is crucial as not all of the species in the genus are toxic. In this study, morphological characteristics of Gambierdiscus species widely used in species identification were analyzed, and the character states coded. Taxon sampling on the large subunit (LSU) rDNA of all Gambierdiscus species were carried out, and used for the phylogenetic reconstruction. The character states were mapped onto the Maximum Parsimony (MP) tree to investigate the character state evolution of Gambierdiscus species. Morphological information and the distribution of the 13 species were used to develop a comprehensive taxonomic database of Gambierdiscus, a web-based interactive identification key for species identification is presented.
\end{abstract}

\begin{abstract}
Genus Gambierdiscus adalah salah satu dinoflagelat bentik marin yang menghasilkan biotoksin penyebab keracunan ikan ciguatera (CFP) pada manusia akibat termakan ikan marin yang tercemar. Dinoflagelat ini biasanya ditemui di perairan tropika dan subtropika yang panas. Fenomena ini yang berkaitan dengan kepadatan sel yang tinggi atau ledakan adalah dirujuk sebagai "Benthic Harmful Algal Bloom (BHAB)". Pengecaman spesis yang tepat adalah penting kerana tidak semua spesies dalam genus ini adalah beracun. Dalam kajian ini, ciri-ciri morfologi digunakan secara meluas dalam pengecaman spesies Gambierdiscus telah dianalisa, dan pengkodan keadaan ciri-ciri ditentukan. Persampelan takson jujukan ribosamal subunit besar (LSU) rDNA semua spesies Gambierdiscus telah dijalankan, dan digunakan untuk pembinaan semula filogenetik. Keadaan ciri-ciri telah dipetakan ke atas pokok kekikiran maksimum (MP) untuk mengkaji evolusi keadaan ciri morfologi spesies Gambierdiscus. Maklumat morfologi 13 spesies dan taburan mereka telah digunakan untuk menghasilkan pangkalan data taksonomi Gambierdiscus yang komprehensif. Kekunci pengecaman spesies interaktif sesawang untuk tujuan pengecaman dibentangkan.
\end{abstract}

(Keywords: Benthic dinoflagellates; ciguatera; harmful; interactive key; morphological characters)

\section{INTRODUCTION}

Harmful benthic dinoflagellates are microalgae that live on the surfaces of marine substrates (e.g. sediments, seaweeds, coral rubbles etc.), and some are associated with the production of marine biotoxins. These biotoxins are capable of causing harmful effects to fish, human and other wildlife [1]. Several other species of BHABs in the genera of Gambierdiscus [2], Ostreopsis [3], Coolia [4], Prorocentrum [3] and Amphidinium [5] are also harmful [6]. The most well-known human intoxication due to benthic dinoflagellates is ciguatera fish poisoning (CFP), where the responsible toxins are produced by some species of Gambierdiscus [7]. It is a common fish poisoning especially in the tropical and subtropical regions [8], with the first case reported from Mauritius, Indian Ocean in 1973 [9]. The biotoxins lipid soluble ciguatoxins and water soluble maitotoxins produced by the toxic Gambierdiscus species accumulate via food chains transfer from herbivorous to carnivorous fishes to the higher tropic levels $[9,10]$.

Early symptoms of CFP occur within hours of fish consumption, with gastrointestinal, neurologic and cardiovascular symptoms observed [7]. CFP has become a world health threat as the reef fish such as barracuda, grouper and snapper are increasingly exported for consumption [8].

The genus Gambierdiscus is relatively easy to identify under light microscope (LM). Most of the species are disc-shaped and anterio-posteriorly 
compressed; the deep hollow sulcus and circular narrow deep cingulum are sometimes visible under LM. The type species, G. toxicus Adachi et Fukuyo was first described from Gambier Islands in the South Pacific Ocean. Species in the genus come in two basic shapes, i.e. globular and anterio-posteriorly compressed. Up till now, 13 Gambierdiscus species that have been described, viz. G. australes Chinain et Faust [11], G. belizeanus Faust [12], G. caribaeus Vandersea, Litaker, Faust, Kibler, Holland et Tester, G. carolinianus Litaker, Vandersea, Faust, Kibler, Holland et Tester, G. carpenteri Kibler, Litaker, Faust, Holland, Vandersea et Tester [13], G. excentricus Fraga [14], G. pacificus Chinain et Faust, G. polynesiensis Chinain et Faust [11], G. ruetzleri Faust, Litaker, Vandersea, Kibler, Holland et Tester [13], G. scabrosus Nishimura, Sato et Adachi [15], G. silvae Fraga et Rodríguez [16], G. toxicus Adachi et Fukuyo [2] and G. yasumotoi Holmes [17]. Species identification in the genus is generally aided by the advanced scanning electron microscopy (SEM), with detailed observations on the thecal architecture. Some of these species possess similar morphological characteristics which make it difficult to distinguish without the taxonomic expertise.

Research interests in benthic dinoflagellates have been increasing in recent years. This is partly due to the increasing information on the blooms and their impacts to other organisms and ecosystems. Species identification is crucial, and requires experienced taxonomists and well-trained personnel in electron microscopy. In a previous work of Litaker et al. (2009), a dichotomous tree detailing the morphological characteristics of ten species of Gambierdiscus was introduced [13]. This study aims to extend the usage of identification keys in an interactive manner to assist in identifying species of
Gambierdiscus. First, the morphology of Gambierdiscus species was characterized based on the previous descriptions as in the literature [2, 11-17]. Evolutionary lineage and character state evolution of these benthic dinoflagellates were determined. The morphological information compiled was used to develop a comprehensive taxonomic database of the 13 valid species of Gambierdiscus. The database was then used to design the web-based interactive identification key for species identification.

\section{MATERIALS AND METHODS}

\section{Taxon sampling, sequence alignment and phylo- genetic reconstruction}

Nucleotide sequences of D8-D10 LSU rDNA of taxonomically recognized species of Gambierdiscus (G. australes, G. belizeanus, G. caribaeus, G. carolinianus, G. carpenteri, G. excentricus, $G$. pacificus, G. polynesiensis, G. ruetzleri, $G$. scabrosus, G. silvae, G. toxicus, and G. yasumotoi) were retrieved from GenBank nucleotide database (NCBI) (Table 1). Sequence of Ostreopsis ovata (KJ781420) and Coolia monotis (KF896856) were used as outgroups in this study. The sequences were aligned and edited by using BioEdit Sequence Alignment Editor, ver. 7.0.9.0 [18] and ClustalX 2.0 [19]. Maximum parsimony (MP) was performed with PAUP* ver. 4.0b.10 [20]. A total of 1000 random additions were performed in the analysis by using heuristic search option and a branch-swapping algorithm with three-bisection reconnection (TBR). Tree bootstrapping was performed with 1000 replications to find the robustness of the topologies.

Table 1. Nucleotide sequences of the LSU rRNA gene of Gambierdiscus species used in this study, with their strain designation and GenBank accession numbers.

\begin{tabular}{ccc}
\hline Taxon & Strain & GenBank accession \\
\hline Gambierdiscus australes & 177 & EU770659 \\
Gambierdiscus belizeanus & CCMP399 & EU498034 \\
Gambierdiscus caribaeus & TT302B & EU770686 \\
Gambierdiscus carolinianus & NOAA6 & EU498037 \\
Gambierdiscus carpenteri & CCMP1654 & EU770676 \\
Gambierdiscus excentricus & VGO792 & JF303076 \\
Gambierdiscus pacificus & CCMP1650 & EU498016 \\
\hline
\end{tabular}


Table 1. Continued

\begin{tabular}{ccc}
\hline Taxon & Strain & GenBank accession \\
\hline Gambierdiscus polynesiensis & TB-92 & EU498078 \\
Gambierdiscus ruetzleri & NOAA22 & EU498081 \\
Gambierdiscus silvae & VGO1022 & JF303077 \\
Gambierdiscus scabrosus & G1G & AB765912 \\
Gambierdiscus toxicus & HIT-91 & EU498026 \\
Gambierdiscus yasumotoi & - & EU498086 \\
Coolia monotis & Dn89EHU & KF896856 \\
\hline
\end{tabular}

Morphological character coding, matrix construction and character state evolution

Morphometric data of the 13 species were compiled based on literatures $[2,12-17,21]$ as well data obtained in this study. The described morphological characters that are used in Gambierdiscus taxonomic. classification were assigned for character coding (Table 2). The character matrix was then constructed by using the program NEXUS data editor ver. 0.5.0 [22] (Table 3). All characters were treated as unordered. The character states were mapped onto the MP tree by considering the parsimony ancestral state using Mesquite ver. 2.75 [23]

Table 2. Morphological characters of Gambierdiscus analyzed and their possible character states. Schematic illustration of some characters is shown in Figure 2.

\begin{tabular}{|c|c|c|c|}
\hline & Character & Character states & Description \\
\hline \multirow[t]{2}{*}{ A } & Cell shape & 0 & Globular \\
\hline & & 1 & Anterio-posteriorly compressed \\
\hline \multirow[t]{4}{*}{ B } & Cell length & 0 & Length of $30-40 \mu \mathrm{m}$ \\
\hline & & 1 & Length of $40-50 \mu \mathrm{m}$ \\
\hline & & 2 & Length of $50-60 \mu \mathrm{m}$ \\
\hline & & 3 & Length of $60-70 \mu \mathrm{m}$ \\
\hline \multirow[t]{3}{*}{$\mathrm{C}$} & Cell width & 0 & $30-50 \mu \mathrm{m}$ \\
\hline & & 1 & $50-70 \mu \mathrm{m}$ \\
\hline & & 2 & $70-90 \mu \mathrm{m}$ \\
\hline \multirow[t]{3}{*}{$\mathrm{D}$} & Cell depth & 0 & $40-60 \mu \mathrm{m}$ \\
\hline & & 1 & $60-80 \mu \mathrm{m}$ \\
\hline & & 2 & $80-100 \mu \mathrm{m}$ \\
\hline \multirow[t]{4}{*}{$\mathrm{E}$} & Po marginal pores abundancy & 0 & $10-20$ \\
\hline & & 1 & $20-30$ \\
\hline & & 2 & $30-40$ \\
\hline & & 3 & $40-50$ \\
\hline \multirow[t]{3}{*}{$\mathrm{F}$} & Po plate & 0 & Ellipsoid, fishhook-shaped/comma-shaped \\
\hline & & 1 & Elongated, narrow fishhook-shaped \\
\hline & & 2 & Oval, fishhook-shaped \\
\hline \multirow[t]{3}{*}{ G } & $4^{\prime}$ plate & 0 & Broad, wedged, hexagonal \\
\hline & & 1 & Broad, wedged, pentagonal \\
\hline & & 2 & Narrow, wedged, pentagonal \\
\hline \multirow[t]{2}{*}{$\mathrm{H}$} & $2^{\prime}$ plate & 0 & Hatched, long, asymmetrical \\
\hline & & 1 & Rectangular, long, symmetrical \\
\hline
\end{tabular}


Table 2. Continued

\begin{tabular}{cccc}
\hline & Character & Character states & Description \\
\hline I & $3^{\prime \prime}$ plate & 0 & Symmetric \\
J & & 1 & Asymmetric \\
& $2^{\prime \prime \prime \prime}$ plate & 0 & Broad, long, pentagonal \\
K & Cingulum & 1 & Narrow, long, pentagonal \\
& & 0 & Narrow \& deeply excavated \\
& & 1 & Lipped \\
& & 2 & Descendent \\
L & Sulcus & 0 & Equivocal \\
& & 1 & Deeply concaved \\
& & 2 & Deep \\
& & 3 & Broad \\
& & 5 & Short \\
& & 0 & Hollow \\
& & 1 & Equivocal \\
M & Thecal surface & & Heavily-areolated \\
& & & Smooth \\
\hline
\end{tabular}

Table 3. Distribution of character states among Gambierdiscus taxa for the 13 morphological char-acters $(\mathrm{A}-\mathrm{M})$ used in the character state evolution analysis.

\begin{tabular}{lccccccccccccc}
\hline \multirow{2}{*}{ Species } & \multicolumn{10}{c}{ Characters and character states } \\
\cline { 2 - 14 } & A & B & C & D & E & F & G & H & I & J & K & L & M \\
\hline Gambierdiscus australes & 1 & 0 & 1 & 1 & 2 & 0 & 2 & 1 & 1 & 1 & $?$ & $?$ & 1 \\
Gambierdiscus belizeanus & 1 & 1 & 1 & 1 & 1 & 0 & 2 & 0 & 1 & 1 & $?$ & $1 / 3$ & 0 \\
Gambierdiscus caribaeus & 1 & $2 / 3$ & 2 & 2 & 3 & 0 & 1 & 1 & 0 & 0 & 0 & 1 & 1 \\
Gambierdiscus carolinianus & 1 & 2 & 2 & 1 & 3 & 0 & 1 & 0 & 1 & 0 & 1 & 1 & 1 \\
Gambierdiscus carpenteri & 1 & 2 & 2 & 2 & 3 & 0 & 1 & 1 & 1 & 0 & 0 & 1 & 1 \\
Gambierdiscus excentricus & 1 & 0 & 2 & 2 & 2 & 2 & 2 & 1 & 1 & 1 & 2 & 4 & 1 \\
Gambierdiscus pacificus & 1 & 2 & 1 & 0 & 2 & 0 & 2 & 1 & 0 & 1 & $?$ & $?$ & 1 \\
Gambierdiscus polynesiensis & 1 & 1 & 1 & 1 & 3 & 0 & 1 & 0 & 1 & 0 & $?$ & $?$ & 1 \\
Gambierdiscus ruetzleri & 0 & 2 & 0 & 0 & 3 & 1 & 2 & 0 & 0 & 1 & $?$ & 1 & 1 \\
Gambierdiscus scabrosus & 1 & 0 & 1 & 1 & 1 & 0 & 0 & 1 & 1 & 1 & 0 & 1 & 0 \\
Gambierdiscus silvae & 1 & 1 & 2 & 2 & 2 & 2 & 0 & 0 & 1 & 0 & 0 & 3 & 1 \\
Gambierdiscus toxicus & 1 & 2 & 2 & 2 & 3 & 0 & 1 & 0 & 1 & 0 & 0 & 0 & 1 \\
Gambierdiscus yasumotoi & 0 & 3 & 1 & 0 & 1 & 1 & 2 & 0 & 1 & 1 & $?$ & 2 & 1 \\
\hline
\end{tabular}

Development of the web-based interactive identification key

An interactive identification key of Gambierdiscus was illustrated based on the morphological data of the 13 species of Gambierdiscus. The web-based key was created using 3I (Internet-accessible
Interactive Identification) Interactive Key and the Taxonomic Database Software Package [24]. The database comprised of 13 morphological characters; four of the characters were numerical, which are based on morphological measurements. 


\section{RESULTS AND DISCUSSION}

\section{Phylogenetic inference}

The phylogenetic inference of Gambierdiscus species based on MP revealed two monophyletic clades, G1 and G2 (Figure 1). Species of
Gambierdiscus with anterio-posteriorly compressed cell-shape were grouped in G1, albeit weak bootstrap support (51\%). Gambierdiscus ruetzleri and G. yasumotoi were grouped as G2, both shared similar globular cell-shape morphology, and the clade was strongly supported (100\%). This topology is consistent with those reported previously [11-16].

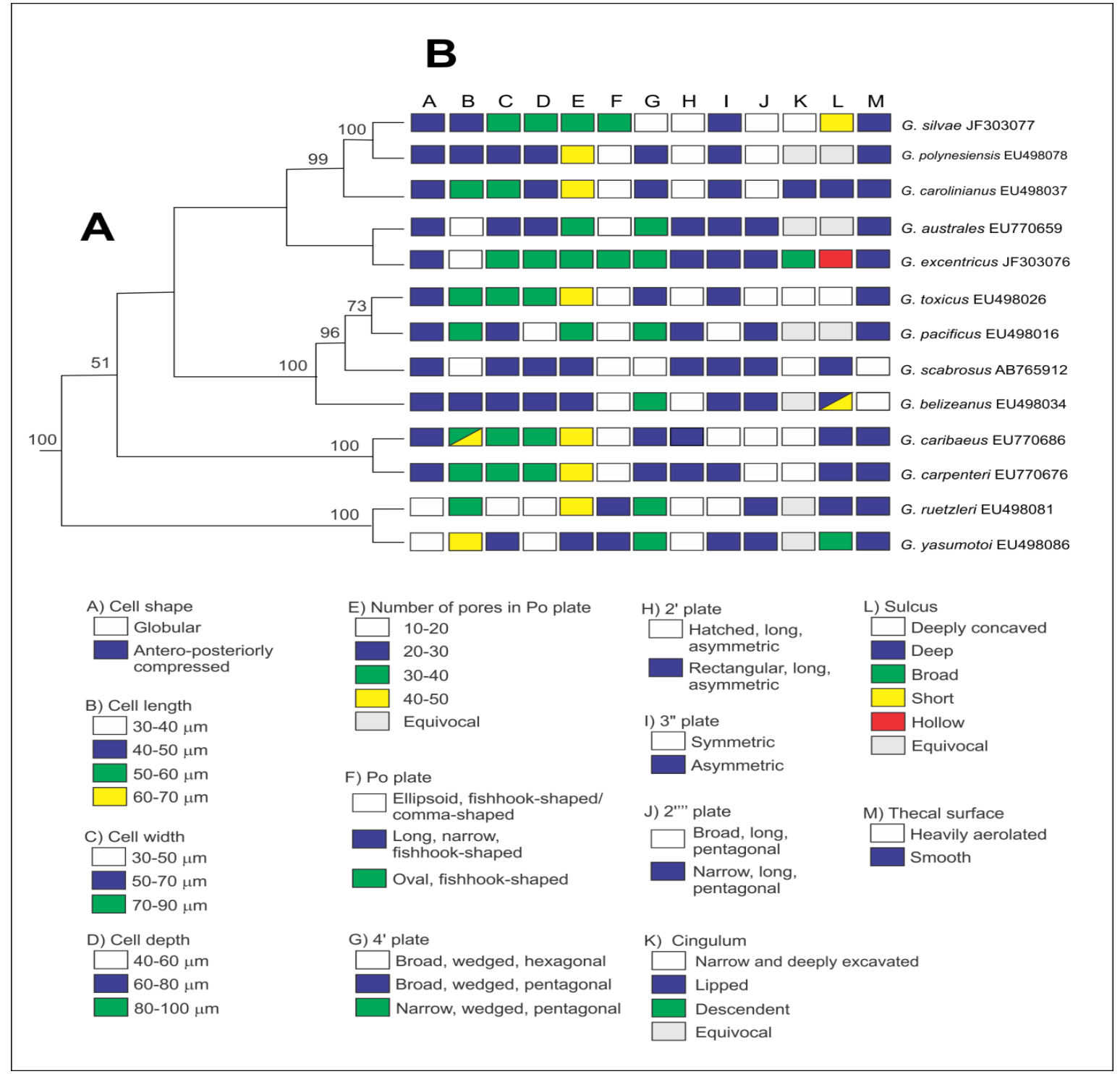

Figure 1. Character state evolution of Gambierdiscus. (A) Phylogenetic tree inferred from LSU rDNA (D8D10) of Gambierdiscus species. Bootstrap values are given. (B) Mapping of charater states of each species as shown in color boxes. Legends for the 13 morphological characters $(\mathrm{A}-\mathrm{M})$ and their states are present.

\section{Character state evolution}

The morphological characteristics of Gambierdiscus have been well described [1117,21,25]. Gambierdiscus species were identified and characterized based on their cell size and shape, architecture of thecal plates as well as cell surface morphology $[11,13]$. Some of the morphological features are of taxonomic informative and useful in identifying and discriminating species of Gambierdiscus. Among the characters scored and the characters mapped on the MP tree, the most consistent morphological characters appear to be the cell shapes (Figure 1, character A) and the thecal 
surface (Figure character M). Character A supported the separation of the two major clades, with the states of anterio-posteriorly compressed and globular morphology distributed in G1 and G2, respectively (Figure 1). The globular morphology of G. ruetzleri and G. yasumotoi has been acknowledged as a plesiomorphic trait, and forms a transition point and derived to the synapomorphic anterio-posteriorly compressed trait. These two Gambierdiscus species were relatively diverged in the early evolution of the genus compared to the anterio-posteriorly compressed species [13]. Gambierdiscus ruetzleri and G. yasumotoi share the same cell shape but could be easily distinguished based on cell sizes; where G. ruetzleri is smaller than G. yasumotoi. Besides, the number of marginal pore in the apical pore $(\mathrm{Po})$ plate and the third precingular plate ( $\left.3^{\prime \prime}\right)$ of $G$. yasumotoi differ from those of G. ruetzleri.

In distinguishing species among the anteriosteriorly compressed species, they can be differentiated based on their second and fourth apical plates (2' and 4'). According to Nishimura et al. (2014), G. scabrosus was morphologically similar to $G$. belizeanus. However, their detailed morphological assessment revealed that the species can be readily differentiated from $G$. belizeanus based on the characteristics of 4' plate; G. belizeanus possesses narrow, wedged, pentagonal 4' plate, but $G$. scabrosus has broad, wedged, hexagonal 4' plate (Figure 1). Apart from that, G. belizeanus and $G$. scabrosus also can be distinguished based on the shape of 2' plate $[15,21]$. The synapormorphic state of heavily-aerolated thecal surface (character M) is in good agreement with the phylogenetic clustering of the species (Figure 1).

Most taxa in G1 and G2 are characterized by the number of marginal pores between $40-50$ pores, except $G$. pacificus that contained $30-40$ pores [11] (Figure 1, character E). Gambierdiscus caribaeus was morphologically very similar to $G$. carpenteri, where 11 out of 13 described morphological characters appeared to be identical, except cell length (character B) and the symmetrical feature of 3 " plate (character I).

Our character state analysis revealed that the state of ellipsoid, fishhook-shaped or comma-shaped of Po is common among the species of Gambierdiscus, with exceptions of G. scabrosus and G. silvae that have oval, fishhook-shaped Po (character F). The two newly described species have a broad, wedged, hexagonal 4' plate; while most Gambierdiscus species have a pentagonal shape of $4^{\prime}$ (character $\mathrm{G})$. For the characters of cingulum and sulcus, most species were equivocal, but several were coded as missing data as no information is available (character $\mathrm{K}$ and $\mathrm{L}$ ).

Gambierdiscus australe and G. excentricus are closely related, but can be distinguished by thier cell sizes and Po. The former is smaller in size and with an ellipsoid Po plate; unlike G. excentricus that has oval Po plate. The characteristic of Po has been previously described as either fishhook-shaped or comma-shaped by various researchers even for the same species of Gambierdiscus [e.g. 12, 21]. Thus, we consider the two fishhook- and comma-shape of Po are similar. In our character state coding, we assign herein the states based on the shape of Po plate, viz. ellipsoid, elongated and oval (Table 2, Figure 2). The diagnostic characters and their states used in differentiating the species of Gambierdiscus are illustrated in Figure 2.

\section{Web-based interactive identification key}

A total of 13 described species of Gambierdiscus was compiled in the $3 \mathrm{i}$ taxonomic database for species identification (Figure 3). The character states for each species were input in Microsoft Access 2010 (Microsoft Inc.) as tabulated in Table 3. The web-based interface of the key is accessible via http://dmitriev.speciesfile.org/key. asp?key=Bacillariales\&lng=En\&i=1\&keyN=1.

Species identification started by choosing a state in character from the drop-down box. The range of valid values was shown in square brackets for the characters with numerical values. The character form is useful where user can input data obtain from either LM or SEM to begin their identification. Character states are chosen based on the states that have been keyed in and numerical character is input as in the range given. The list of taxa that fit the search criteria is updated and displayed after the $<$ Proceed $>$ button is pressed (Figure 3 ). The database provides a schematic drawing of some selected morphological characters, where users can decide which characters state to choose by viewing the illustrated character states that are linked to the character. The [remaining taxa] section displays a list of taxa after the search while the [eliminated taxa] section displays the non-matching species.

The database also provides other information such as global distribution of each taxa, their related 
references and links to other sources such as GenBank. For example, the distribution of each species is updated based on literature, with GPS location if available.

Besides that, the $<$ Preference $>$ button allows user to modify the interface. This includes options

\section{Cell Shape}

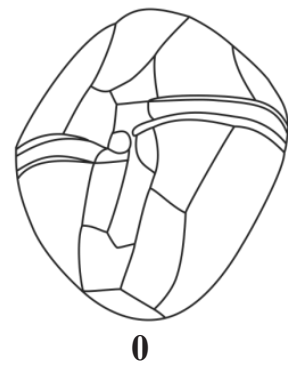

2' Plate

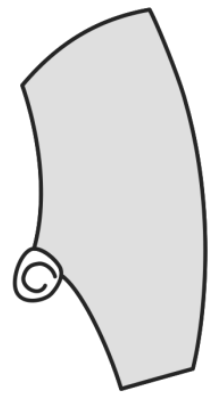

0

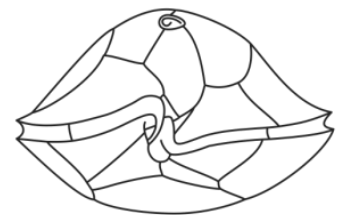

1

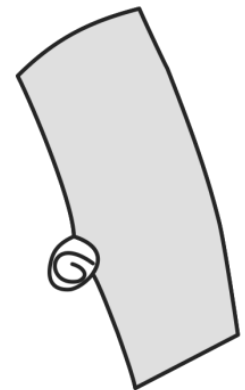

1 for sorting the character list and changing the error of tolerance [24]. The $<$ Compare $>$ button is useful for user to make comparison between two or more species of Gambierdiscus selected. All features including illustrative images, similarities, and diagnostic features are included in this autogenerated function.

\section{3" Precingular plate}

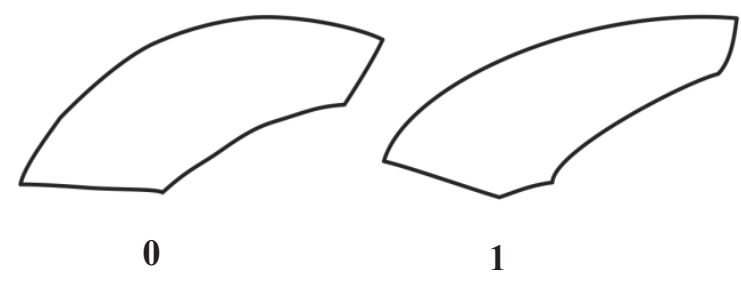

2"'Plate
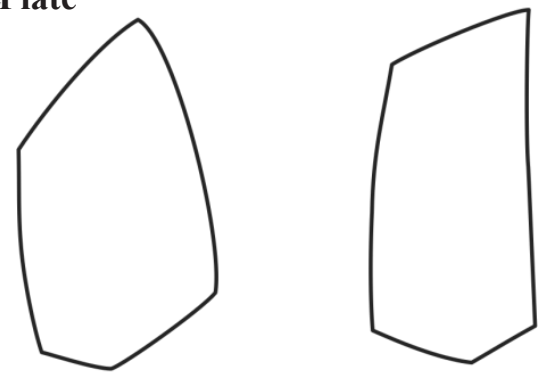

$\mathbf{0}$

\section{4' Plate}

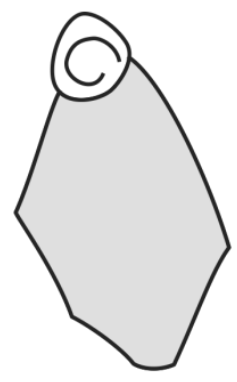

0

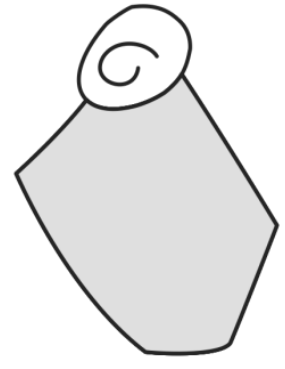

1

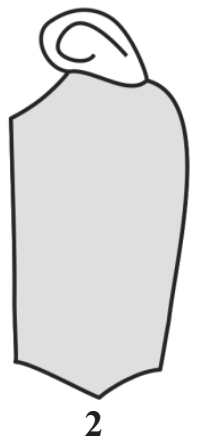

Aprical pore plate

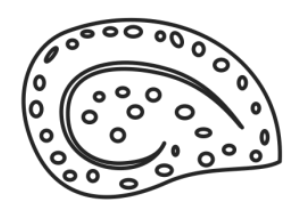

0

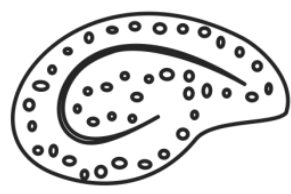

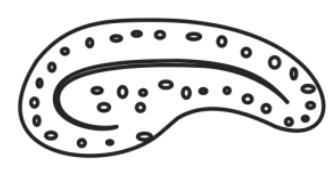

1

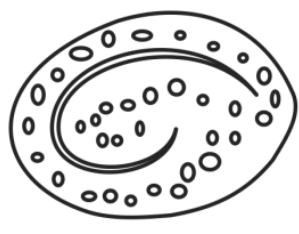

2

Figure 2. A schematic drawing of some morphological characters. Numbers indicate character states. 


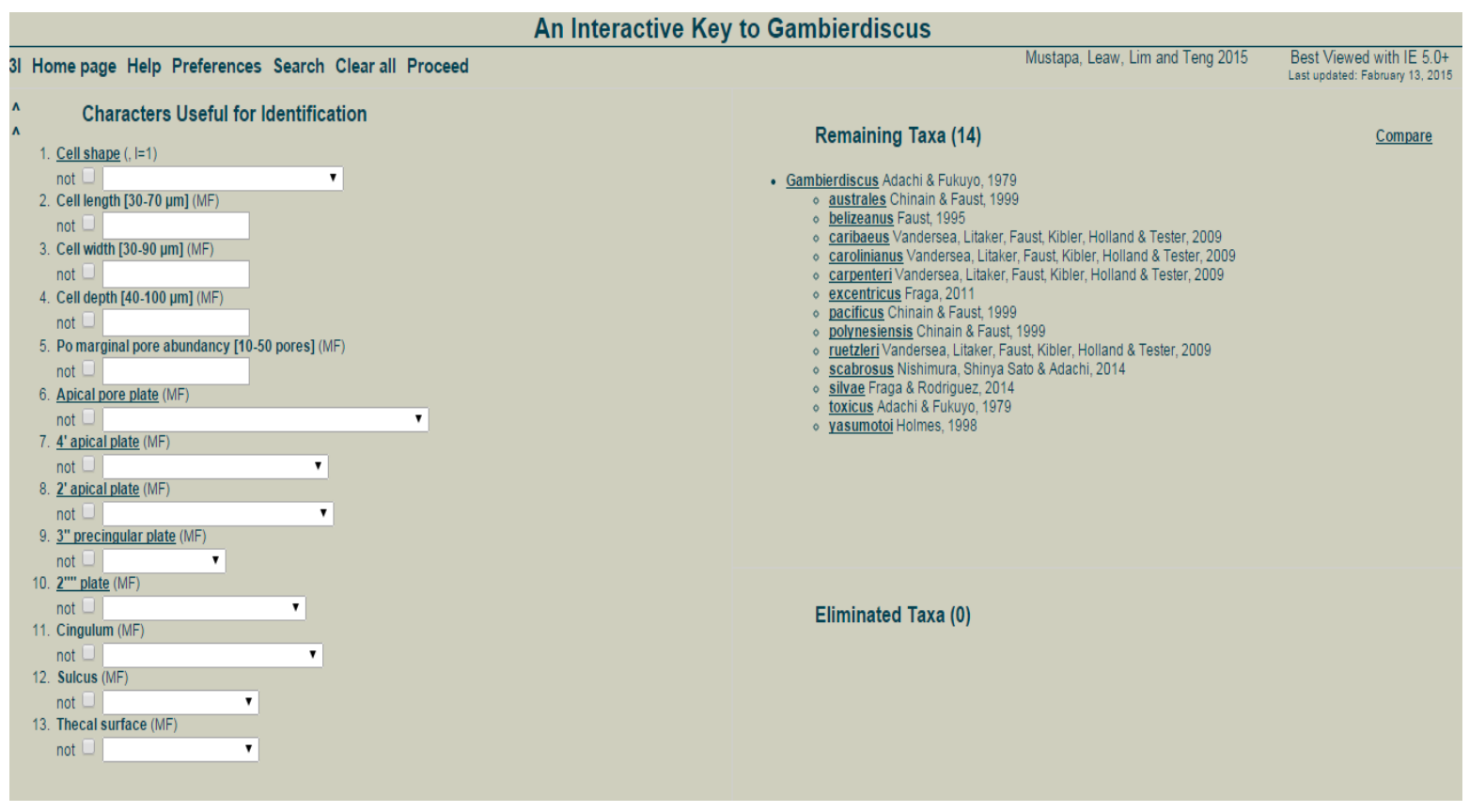

Figure 3. The web interface of $3 i$ key to the species of Gambierdiscus.

\section{CONCLUSION}

Our analysis of character state evolution in this study has strengthened the current well-established morphology-based taxonomy of Gambierdiscus. Mapping of these known morphological characteristics on a phylogenetic tree revealed several characters that are taxonomic informative. In fact, it provides a basis for future characters sampling. The web-based interactive key developed could serve as a platform to assist in species identification.

Note that the two globular species, G. yasumotoi and G. rutzleri have recently been transferred to a new genus, Fukuyoa Gomez, Qiu, Lopes et Lin when this paper was undergone publishing process. The database is now updated.

\section{ACKNOWLEDGEMENTS}

This work was funded by the Malaysian government through the Ministry of Education under JSPS COMSEA Matching Fund (GA002-2014), RACE, and $\mathrm{HiCoE}$ Fund (IOES-2014C); the University of Malaya under UMRP (RU006A-2014, RU006B-2014) and BKP (BK013-2014). The authors are grateful to Dr. Dmitry A. Dmitriev (University of Illinois at Urbana-Champaign, USA) to guide in developing the $3 \mathrm{i} \mathrm{key}$, and hosting the database in the $3 \mathrm{i}$ web interface; we also thank Dr. Patricia Tester (Center for Coastal Fisheries \& Habitat Research, NOAA) for her review of the manuscript.

\section{REFERENCES}

1. Camacho F. G., Rodríguez J. G., Mirón A. S., García M. C. C., Belarbi E. H., Chisti Y. and Grima E. M. (2007). Biotechnological significance of toxic marine dinoflagellates. Biotechnol. Adv. 25: 176-194.

2. Adachi R. and Fukuyo Y. (1979). The thecal structure of a marine toxic dinoflagellate Gambierdiscus toxicus gen. et sp. nov. collected in a ciguatera-endemic area. B. Jpn. Soc. Sci. Fish. 45: 67-71.

3. Fukuyo Y. (1981). Taxonomical study on benthic dinoflagellates collected in coral reefs. B. Jpn. Soc. Sci. Fish. 47: 967-978.

4. Besada E. G., Loeblich L. A. and Loeblich Iii, A. R. (1982). Observations on tropical, benthic dinoflagellates from ciguatera-endemic areas: Coolia, Gambierdiscus, and Ostreopsis. B. Mar. Sci. 32: 723-735.

5. Claparède R. É. and Lachmann J. (1859). 
Études sur les infusoires et les rhizopodes. Mémoires de 1〉Institut National Genevois 6: 261-482.

6. Yasumoto T., Seino N., Murakami Y. and Murata M. 1987. Toxins produced by benthic dinoflagellates. The Biological Bulletin 172: 128-131.

7. Friedman M. A., Arena P., Levin B., Fleming L., Fernandez M., Weisman R., Bernstein J., Schrank K., Blythe D., Backer L. and Reich A. (2007). Neuropsychological study of ciguatera fish poisoning: a longitudinal casecontrol study. Arch. Clin. Neuropsych. 22: 545-553.

8. Lehane L. and Lewis R. (2000). Ciguatera: recent advances but the risk remains. Int. J. Food Microbiol. 61: 91-125.

9. Quod J. P. and Turquet J. (1996). Ciguatera in Reunion Island (SW Indian Ocean): epidemiology and clinical patterns. Toxicon 34: 779-785.

10. Gillespie N. C., Lewis R. J., Pearn J. H., Bourke A. T., Holmes M. J., Bourke J. B. and Shields W. J. (1986). Ciguatera in Australia. Occurrence, clinical features, pathophysiology and management. The Medical Journal of Australia 145: 584-590.

11. Chinain M., Faust M. A., and Pauillac S. (1999). Morphology and moleular analyses of three of Gambierdiscus(Dinophyceae): Gambierdiscus pacificus sp. nov., Gambierdiscus australes sp. nov., and Gambierdiscus polynesiensis sp. nov. J. Phycol. 35: 1282-1296.

12. Faust M. A. (1995). Observation of sanddwelling toxic dinoflagellates (Dinophyceae) from widely differing sites, including two new species. J. Phycol. 31: 996-1003.

13. Litaker R. W., Vandersea M. W., Faust M. A., Kibler S. R., Chinain M., Holmes M. J., Holland W. C. and Tester P. A. (2009). Taxonomy of Gambierdiscus including four new species, Gambierdiscus caribaeus, Gambierdiscus carolinianus, Gambierdiscus carpenteri and Gambierdiscus ruetzleri (Gonyaulacales, Dinophyceae). Phycologia
48: 344-390.

14. Fraga S., Rodríguez F., Caillaud A., Diogène J., Raho N. and Zapata M. (2011). Gambierdiscus excentricus sp. nov. (Dinophyceae), a benthic toxic dinoflagellate from the Canary Islands (NE Atlantic Ocean). Harmful Algae 11: 1022.

15. Nishimura T., Sato S., Tawong W., Sakanari H., Yamaguchi H. and Adachi, M. (2014). Morphology of Gambierdiscus scabrosus sp. nov. (Gonyaulacales): a new epiphytic toxic dinoflagellate from coastal areas of Japan. $J$. Phycol. 50: 506-514.

16. Fraga S. and Rodríguez F. (2014). Genus Gambierdiscus in the Canary Islands (NE Atlantic Ocean) with description of Gambierdiscus silvaesp.nov., a new potentially toxic epiphytic benthic dinoflagellate. Protist 165: 839-853.

17. Holmes M. J. (1998). Gambierdiscus yasumotoi sp. nov. (Dinophyceae), a toxic benthic dinoflagellate from southeastern Asia. J. Phycol. 34: 661-668.

18. Hall T. A. (1999). BioEdit: a user-friendly biological sequence alignment editor and analysis program for Windows 95/98/NT. Nucl. Acid. S. 41: 95-98.

19. Thompson J. D., Gibson T. J., Plewniak F., Jeanmougin F. and Higgins D. G. (1997). The ClustalX windows interface: flexible strategies for multiple sequence alignment aided by quality analysis tools. Nucl. Acid. Res. 25: 4876-4882.

20. Swofford D. L. 2003. PAUP*. Phylogenetic Analysis Using Parsimony (*and Other Methods). Sinauer Associates, Sunderland, Massachusetts.

21. Leaw C. P., Lim P. T., Tan T. H., TuanHalim T. N., Cheng K. W., Ng B. K. and Usup G. (2011). First report of the benthic dinoflagellate, Gambierdiscus belizeanus (Gonyaulacales: Dinophyceae) for the east coast of Sabah, Malaysian Borneo. Phycol. 
Res. 59: 143-146.

22. Page R. (2001). NEXUS Data Editor 0.5.0. Program available at http://taxonomy. zoology.gla.ac.uk/rod/NDE/nde.html.

23. Maddison W. and Maddison D. 2007. Mesquite: a modular system for evolutionary analysis. Version 2.75. 2011. URL http:// mesquiteproject.org.
24. Dmitriev D. A. (2003). 3I Interactive Keys and Taxonomic Databases [Online]. Available: http://dmitriev.speciesfile.org/ [Accessed 13 February 2015].

25. GEOHAB 2012. Global Ecology and Oceanography of Harmful Algal Blooms, GEOHAB Core Research Project: HABs in Benthic Systems. E. Berdalet, P. Tester, A. Zingone (Eds.) IOC of UNESCO and SCOR, Paris and Newark, 64 pp. 